Journal of Applied Finance \& Banking, Vol. 12, No. 1, 2022, 47-68

ISSN: 1792-6580 (print version), 1792-6599(online)

https://doi.org/10.47260/jafb/1213

Scientific Press International Limited

\title{
Nonlinear Short-Run Adjustments between REITs and Stock Markets in the USA and Australia
}

\author{
Cheng-Wen Lee ${ }^{1}$ and Wei-Jui Chen ${ }^{2}$
}

\begin{abstract}
This study examines whether nonlinear co-integration exists between real estate investment trusts (REITs) and corresponding stock markets in the United States and Australia. Moreover, we employ the smooth-transition, vector-error correction model (STVECM) including the generalized autoregressive conditional heteroskedasticity (GARCH) model to separately explore the adjustment efficiencies of the short-run REITs and corresponding stock returns in dynamics. The empirical results demonstrate that there is a nonlinear co-integration with structural breaks between the equity and mortgage REITs and stock markets in the US as well as between the REITs and stock markets in Australia. When large positive and negative deviations of STVECM exist, the speed of equilibrium adjustment of the S\&P 500 index is greater than that of the Mortgage REITs index. Additionally, the higher the equilibrium adjustment of Australian/US REITs index, the greater the reversion of Australian/US REITs index. Meanwhile, this study is also interested in finding out whether the REIT indices in the US or Australia would serve as a leading indicator for price movements. The result findings may provide a good reference for the investors' investment engaged in the areas of these two countries.
\end{abstract}

JEL Classification: C22, D53, G14, L85.

Keywords: REITs, STVECM, Nonlinear Granger causality, GARCH.

1 Department of International Business, Chung Yuan Christian University, Taoyuan City, Taiwan.

2 Ph.D. Program in Business, College of Business, Chung Yuan Christian University, Taoyuan City, Taiwan.

Article Info: Received: December 29, 2021. Revised: January 5, 2022.

Published online: January 9, 2022. 


\section{Introduction}

As of December 2010, the global market capitalization of real estate investment trusts (REITs) has surpassed USD 800 billion, with nearly 500 fund management units. Thus, REITs have become another favourite choice among investors besides the stock market. Since real estate properties can preserve value while REITs increase liquidity and financial transparency, investors who previously invested only in highly liquid and profitable stocks are now including an increasing number of real-estate related securities into their portfolios to diversify their investment risk. Considering that the effect to diversify risk by investing in the real estate market of different countries may not be inferior to the effect of investing in the stock and real estate markets, this study also examines the real estate price movements of two different countries and the impact they may have on the investment strategy of investors.

Most literatures have confirmed the co-integration between the real estate and stock markets (Tuluca, Myer, and Webb, 2000; Liow and Yang, 2005; and Hui and Yue, 2006). If nonlinear characteristics significantly exist in the time series, the testing power of a traditional linear model may abruptly drop. Considering that the REIT indices and corresponding stock indices may change over time in a long-term time series, this study uses the residual-based test for co-integration with structural breaks proposed by Gregory and Hansen (1996) to analyze the time-series cointegration between the REIT index and corresponding stock index. Wilson and Okunev (1997) found that a nonlinear relationship exists between the real estate and stock markets. However, the extent of their mean reversion was quite slow and deviations between the two markets could be prolonged. Subsequently, Wilson and Okunev (1999) used fractional co-integration to find no co-memories between the stock and property markets in the United States and United Kingdom, but they found some evidence of long co-memories in Australia on either side of the 1987 in spite of no co-memory during the entire period. By using the non-parametric rank test, $\mathrm{Su}$ (2011) examined whether a nonlinear long-run equilibrium exists between the real estate and stock markets in western European countries and his result demonstrated strong evidence for nonlinear adjustments when there was deviation from a long-run equilibrium. In addition, by utilising the threshold auto-regressive (TAR) model, Su, Chang, and Zhu (2011) tested whether a long-run relationship existed between the real estate and stock markets in European countries, and found that the dynamics reverting to a long-run equilibrium did follow nonlinear adjustments with a specific threshold value.

Considering that structural break may lead to a nonlinear relationship between the real estate and stock markets, this study adopts the nonlinear model to analyse the respective behaviours of short-term mean reversion for the two markets when they deviate from the long-run equilibrium relationship. The phenomenon of non-linear mean reversion between each real estate market and stock market does not necessarily follow the results of long memory. However, the theory of interaction between noise and arbitrage traders have proposed that arbitrageurs must be aware 
of the potential for noise traders in order to drive returns further away from equilibrium before correction. To be more specific, the dynamics governing small return deviations from the equilibrium differs at least from the dynamics governing large return deviations. In this case, the smooth transition vector error-correction model (STVECM) should be able to capture the real estate and stock market dynamics with large and small returns and allow the gradual movement between the different regimes In addition, the high-frequency financial asset prices may fluctuate in clusters. Therefore, after confirming the co-integration relationship (with structural breaks) between the REITs and corresponding stock price indices, this study further explores whether the STVECM with the GARCH model can accurately describe the dynamic adjustments in reverting to long-run equilibrium between the REITs and corresponding stock price indices.

Past literatures have not reached a consistent conclusion on the lead-lag relationship of the stock and real estate markets, which included 'wealth effect' and 'credit price effect'. In regard to the wealth effect, Chau, Ma, and Ho (2000) pointed out that the rise of the S\&P 500 index would result in the decline of Jones Lang LaSalle JLW real-estate price indices in the following season. The results of Oppenheimer and Grissom (1998) and Larson (2005) showed that stock indices could serve as a leading indicator for the REITs prices and a rapid reversal of the stock market would lead to the same reaction from the REITs markets. The nonlinear causality test used by Okunev, Wilson, and Zurbruegg (2002) found that Australian stock markets had a significant one-way impact on its real estate markets. In regard to credit price effect, Hui and Yue (2006) found that the prices of used houses in Beijing and Shanghai would affect stock indices in Shanghai but the stock indices did not affect the corresponding housing prices. Moreover, some empirical literatures found that there were two-way relationships between stock and real-estate prices or the causal relationships between the two markets only showed in some areas. According to Green (2002), causality relationships between stock and housing prices did exist in high-priced housing areas but was not significant in areas with low housing prices. The traditional vector auto-regression (VAR) model includes linear predictive ability while disregarding the non-linear effects. Based on the concept of nonparametric statistics and correlation integral, this study adopts the nonparametric non-linear Granger causality test proposed by Hiemstra and Jones (1994) to analyze whether there is either a wealth effect or a credit price effect between the stock and REIT prices in the US and Australia, respectively. Meanwhile, we are also interested in finding out whether the REITs indices in the US or Australia would serve as a leading indicator for price movements.

Real estate securitization originated in the US, whose REITs markets include the longest history and a market capitalization ranks first in the world. Australia developed its REITs in 1971, and its market capitalization ranks second in the world. Due to such rankings, investors will simultaneously allocate their investment in both the stock and real estate securitization markets in the US and Australia in order to diversify risk. Therefore, when interest rates becomes lower and inflation becomes rampant, those who simultaneously invest in real estate securitization and stock 
markets in the US and Australia or those who make investments in the US and Australian real estate securitization markets will be eager to know what the lead-lag relationship is between the REITs and stock markets in these areas. If co-integration with structural breaks exists between the REIT and stock markets in the two countries, people would like to know when the REITs indices and stock indices deviate from their long-run equilibrium respectively and how the two indices can efficiently adjust themselves dynamically and revert to equilibrium. This study further testifies whether co-integration with structural breaks exists between the respective three REITs (i.e., equity, mortgage and hybrid) and stock markets. This study also examines the correlation between the stock and real estate securitization markets in the US and Australia in terms of the overall and classified REIT indices.

\section{Data and Descriptive Analysis}

\subsection{Data range}

The data range of this study consists of the REIT indices and corresponding stock indices in the US and Australia. The REIT indices in the US include the daily REIT indices for all and the equity, mortgage and hybrid types. The corresponding stock price index in the US is the daily S\&P 500 index. The data employed for Australia includes the daily All REIT index and the All Ordinaries index. Since the beginning of the REIT indices in the US and Australia are different, this study utilises the beginning of the REIT index of each country as the beginning of the REIT index and of the stock price index for each country. Thus, the data for the REIT index and the stock price index in the US extend from 1 January 1999 to 2 February 2011 and those for Australia are from 3 March 2000 to 28 February 2011. In addition, the data for the REIT indices in the US and Australia extend from 3 March 2000 to 28 February 2011. The data source for the REIT indices as well as the stock price indices employed in this study is gathered from the DataStream database.

\subsection{Descriptive statistical analysis of the REITs and stock indices}

The results in Table 1 show that the REIT index return average for equity REITs in the US is significantly higher than that of the other four REITs. However, the results of the standard deviation in Table 1 show that the fluctuations in the Hybrid REIT index return in the US are significantly higher than those in the other four REIT index returns. In addition, the average for S\&P 500 index returns in the US is significantly higher than that for ASX index returns in Australia, which indicates that the average stock index return in the US is significantly higher than that in Australia. The standard deviation in the Table 1 shows that the fluctuation in S\&P 500 index returns in the US is higher than that in ASX index returns in Australia, indicating that the risk of S\&P 500 stock index return in the US is higher. From the standard deviation illustrated in the Table 1, the fluctuation is significantly greater regardless of the REIT index returns or stock index returns in the US, which shows a close relationship between the fluctuations in the REIT index and in the stock index. 
Table 1: Descriptive statistics of REIT index/returns in the US and Australia

\begin{tabular}{|l|c|c|c|c|c|c|c|}
\hline \multicolumn{1}{|c|}{ Items } & $\begin{array}{c}\text { US all } \\
\text { REITs }\end{array}$ & $\begin{array}{c}\text { US } \\
\text { EQUITY } \\
\text { REITs }\end{array}$ & $\begin{array}{c}\text { US } \\
\text { MORTGAGE } \\
\text { REITs }\end{array}$ & $\begin{array}{c}\text { US } \\
\text { HYRID } \\
\text { REITs }\end{array}$ & $\begin{array}{l}\text { Aus. all } \\
\text { REITs }\end{array}$ & S\&P 500 & Aus. ASX \\
\hline Mean & 0.000147 & 0.000183 & -0.000263 & -0.000261 & -0.00012 & $2.42 \mathrm{E}-05$ & 0.000162 \\
\hline Median & 0.000000 & 0.000000 & 0.000000 & 0.000000 & 0.000226 & 0.000146 & 0.000486 \\
\hline Maximum & 0.162366 & 0.168755 & 0.219701 & 0.16378 & 0.080593 & 0.109572 & 0.053601 \\
\hline Minimum & -0.205429 & -0.215324 & -0.192739 & -0.232155 & -0.121282 & -0.094695 & -0.085536 \\
\hline Std. Dev. & 0.019626 & 0.020305 & 0.019555 & 0.02253 & 0.013959 & 0.013294 & 0.010138 \\
\hline Skewness & -0.181449 & -0.195064 & -0.027507 & -0.569542 & -0.90442 & -0.114767 & -0.672606 \\
\hline Kurtosis & 21.08004 & 21.46572 & 26.39837 & 19.77375 & 13.72932 & 10.73365 & 10.33056 \\
\hline Jarque-Bera & 43207.44 & 45072.46 & 72336.7 & 37345.93 & 13669.13 & 7909.275 & 6413.337 \\
\hline & {$[0.000000]$} & {$[0.000000]$} & {$[0.000000]$} & {$[0.000000]$} & {$[0.000000]$} & $0.000000]$ & {$[0.000000]$} \\
\hline LB Q (4) & $111.16^{* * *}$ & $112.76 * * *$ & $30.485^{* * *}$ & $29.836 * * *$ & $25.702 * * *$ & $34.022 * * * *$ & $12.054 * *$ \\
\hline LB Q (8) & $128.63 * * *$ & $128.73 * * *$ & $50.530^{* * *}$ & $40.639 * * *$ & $80.236 * * *$ & $43.190 * * * *$ & $21.990 * * *$ \\
\hline
\end{tabular}

Note: 1 . Numbers in [ ] indicate the p-value of the Jarque-Bera statistics.

2. $* * *$ and $* *$ denote significances at the $1 \%$ and $5 \%$ levels respectively.

\section{Methodology}

\subsection{Nonlinear unit root test}

In order to reinforce the power of the unit root test for the non-linear dynamic adjustments of the REIT and stock indices in the US and Australia, respectively, this study utilises the non-linear KSS stationarity test according to Kapetanios, Shin, and Snell (2003). The goal of the KSS test is to detect the presence of nonstationarity against a non-linear but stationary exponential smooth transition autoregressive (ESTAR) process. Given that $\gamma$ cannot be identified in the null hypothesis, Kapetanios, Shin, and Snell (2003) used the first-order Taylor series to approximately estimate $\left\{1-\exp \left(-\theta Y_{t-1}^{2}\right)\right\}$. The model is expressed as:

$\Delta Y_{t}=\gamma Y_{t-1}\left\{1-\exp \left(-\theta Y_{t-1}^{2}\right)\right\}+\varepsilon_{t}$

For the null hypothesis $\theta=0$, equation (1) can be re-written as:

$\Delta Y_{t}=\zeta+\delta Y_{t-1}^{3}+\sum_{i=1}^{k} \rho_{i} \Delta Y_{t-i}+\varepsilon_{t}, t=1,2, \ldots ., T$

If the estimate does not reject the hypothesis $H_{0}: \delta=0$, the sequence is a unit root; otherwise the sequence is a nonlinear constant ESTAR. The results of the KSS nonlinear stationarity test show that all of the REIT indices and corresponding stock price indices in the US as well as the REIT index and stock price index in Australia are all linear unit roots whose first-order differences are stationary. This confirms 
that the respective REIT indices and stock price indices are I (1) sequences in such areas.

\subsection{Structure break co-integration test}

Considering the tendency that stock price and house price indices most likely change over time, we use the co-integration test proposed by Gregory and Hansen (1996). This test can be used to analyse non-linear co-integration relationships with structural breaks in time series. First, the traditional co-integration model of housing prices $P_{h t}$ and stock prices $P_{s t}$ is assumed as (3):

$$
P_{s t}=\mu_{1}+\alpha_{1} P_{h t}+e_{t}, \quad t=1, \cdots, n,
$$

Nevertheless, it is found that a co-integration relationship may remain for some time and then turn into a new long-term equilibrium relationship. It is therefore required that assumptions of co-integration with structural breaks be changed into an unknown. Furthermore, we consider that structural breaks may occur in both the intercept and the slope. In this case, the dummy variables are established as:

$$
D_{t \tau}=\left\{\begin{array}{lll}
0 & \text { if } & t \leq[n \tau] \\
1 & \text { if } & t>[n \tau]
\end{array}\right.
$$

Among them, $\tau \in(0,1)$ is the unknown structural break point in the time series. In addition, the structural co-integration model can appear in the following three forms:

1. Structural breaks occur in the intercept $(\mathrm{C})$

$$
P_{h t}=\mu_{1}+\mu_{2} D_{t \tau}+\alpha_{1} P_{s t}+e_{t}
$$

a. Structural breaks occur in both the intercept and time trends $(\mathrm{C} / \mathrm{T})$ :

$$
\begin{aligned}
& P_{h t}=\mu_{1}+\mu_{2} D_{t \tau}+\beta_{t} t+\alpha_{1} P_{s t}+e_{t} \\
& P_{\mathrm{lt}}=u_{1}+u_{2} D_{t \tau}+\beta_{t}+\alpha_{1} P_{s t}+e_{r}
\end{aligned}
$$

b. Structural breaks occur in both the intercept and the slope $(\mathrm{C} / \mathrm{S})$ :

$$
P_{h t}=\mu_{1}+\mu_{2} D_{t \tau}+\alpha_{1} P_{s t}+\alpha_{2} P_{s t} D_{t \tau}+e_{t}
$$

Under the assumption of $\tau \in T$, Gregory and Hansen (1996) utilised the above three models in order to make an ordinary least squares (OLS) estimation for each $\tau$ and to obtain the residuals $\hat{e}_{t \gamma}$. The augmented Dickey-Fuller (ADF) statistics 
can be used to regress $\Delta \hat{e}_{t \tau}$ on $\hat{e}_{t-1 \tau}$ and $\kappa$ backward differential $\left(\Delta \hat{e}_{t-1 \tau}, \cdots, \Delta \hat{e}_{t-1 \kappa \tau}\right)$ by OLS estimation, in order to obtain the regression coefficients for $\hat{e}_{t-1 \tau}$. The $t$ statistics are $\operatorname{ADF}(\tau)=\mathrm{t}$ and stat $\left(\hat{e}_{t-1 \tau}\right)$. Its test statistics $\operatorname{ADF} *$ are not the traditional ADF statistics but the minimum statistics that correspond to specific structural break points, defined as:

$\operatorname{ADF}^{*}=\inf \operatorname{ADF}(\tau)$

The critical value of the test statistic is simulated by Gregory and Hansen (1996) using the response surface function. The simulation is also used in our empirical results to obtain the asymptotically distributed critical value shown in the Table 2 .

Table 2: Structural break co-integration tests of REITs and stock indices

\begin{tabular}{|c|c|c|c|c|}
\hline \multicolumn{5}{|c|}{ Panel A: US Various-type REIT and Stock Indices } \\
\hline Index Name & Model Design & Statistics & Structural Break Point & Co-integration \\
\hline \multirow{3}{*}{$\begin{array}{c}\text { S\&P } 500 \\
\text { EQUITY REITS }\end{array}$} & $\mathrm{C}$ & -4.159 & $1999 / 3 / 8$ & No \\
\hline & $\mathrm{C} / \mathrm{T}$ & -4.563 & $1999 / 3 / 12$ & No \\
\hline & $\mathrm{C} / \mathrm{S}$ & -4.538 & $1999 / 3 / 19$ & Yes \\
\hline \multirow{3}{*}{$\begin{array}{c}\text { S\&P } 500 \\
\text { HYBRID REITS }\end{array}$} & $\mathrm{C}$ & -4.082 & $1999 / 3 / 8$ & No \\
\hline & $\mathrm{C} / \mathrm{T}$ & -4.543 & $1999 / 3 / 12$ & No \\
\hline & $\mathrm{C} / \mathrm{S}$ & -4.539 & $1999 / 3 / 23$ & No \\
\hline \multirow{3}{*}{$\begin{array}{c}\text { S\&P } 500 \\
\text { MORTGAGE REITS }\end{array}$} & $\mathrm{C}$ & -4.314 & $1999 / 3 / 8$ & No \\
\hline & $\mathrm{C} / \mathrm{T}$ & -5.171 & 1999/3/9 & Yes \\
\hline & $\mathrm{C} / \mathrm{S}$ & -4.745 & $1999 / 3 / 19$ & Yes \\
\hline \multicolumn{5}{|c|}{ Panel B: Australian REIT and ASX Stock Indices } \\
\hline Index Name & Model Design & Statistics & Structural Break Point & Co-integration \\
\hline \multirow{3}{*}{$\begin{array}{l}\text { ASX Stock Index } \\
\text { REIT Index }\end{array}$} & $\mathrm{C}$ & -4.005 & $2008 / 7 / 21$ & No \\
\hline & $\mathrm{C} / \mathrm{T}$ & -5.057 & $2002 / 6 / 26$ & Yes \\
\hline & $\mathrm{C} / \mathrm{S}$ & -3.745 & $2008 / 11 / 17$ & No \\
\hline \multicolumn{5}{|c|}{ Panel C: US and Australian REIT Indices } \\
\hline Index Name & Model Design & Statistics & Structural Break Point & Co-integration \\
\hline \multirow{3}{*}{$\begin{array}{l}\text { US All REIT Index } \\
\text { Australian REIT Index }\end{array}$} & $\mathrm{C}$ & -4.731 & $2007 / 5 / 16$ & Yes \\
\hline & $\mathrm{C} / \mathrm{T}$ & -3.864 & $2008 / 1 / 4$ & No \\
\hline & $\mathrm{C} / \mathrm{S}$ & -4.373 & $2007 / 5 / 18$ & No \\
\hline
\end{tabular}

Note: Statistics indicate the $A D F^{*}$ statistics defined in equation (8). 


\subsection{Nonlinearity test and estimations of the STVECM-GARCH}

In order to review the different return dynamics for both the small and large deviations from the co-movements between the stock and REIT prices in the US and Australia separately, this study applies the STVECM to allow for a smooth transition for return dynamics in different regimes. Meanwhile, we let the residuals in this model follow a GARCH process in order to capture the heterogeneity of the residuals. However, if a co-integration does not exist between the stock and REIT prices in any such location, the study uses the STVECM to smoothly transform the return dynamics in different regimes to capture the different dynamics of the stock and REIT price returns in the lower and higher return regimes. In addition, we let the residuals in the STVECM follow a GARCH process. Thus, the STVECMGARCH can be expressed as follows:

$$
\begin{aligned}
& \Delta P_{i}^{h}=\left(\alpha_{0}^{h}+\alpha_{1}^{h} Z_{t-1}+\sum_{i=1}^{q} \alpha_{i+1}^{h} \Delta P_{t-i}^{s}+\sum_{i=1}^{q} \alpha_{t+1+q}^{h} \Delta P_{t-i}^{h}\right)+\left(\beta_{0}^{h}+\beta_{1}^{h} Z_{t-1}+\sum_{i=1}^{q} \beta_{i+1}^{h} \Delta P_{t-i}^{s}\right. \\
& \left.+\sum_{i=1}^{q} \beta_{t+1+q}^{h} \Delta P_{t-i}^{h}\right) F\left(Z_{t-d}: \gamma, \tau\right)+\varepsilon_{t}^{h} \\
& \Delta P_{i}^{s}=\left(\alpha_{0}^{s}+\alpha_{1}^{s} Z_{t-1}+\sum_{i=1}^{q} \alpha_{i+1}^{s} \Delta P_{t-i}^{s}+\sum_{i=1}^{q} \alpha_{t+1+q}^{s} \Delta P_{t-i}^{h}\right)+\left(\beta_{0}^{s}+\beta_{1}^{s} Z_{t-1}+\sum_{i=1}^{q} \beta_{i+1}^{s} \Delta P_{t-i}^{s}\right. \\
& \left.+\sum_{i=1}^{q} \beta_{t+1+q}^{s} \Delta P_{t-i}^{h}\right) F\left(Z_{t-d}: \gamma, \tau\right)+\varepsilon_{t}^{s} \\
& h_{h, t}=\phi_{0}+\phi_{1} \varepsilon_{k_{h, t-1}}^{2}+\phi_{2} h_{h, t-1} \\
& h_{s, t}=\delta_{0}+\delta_{1} \varepsilon_{s, t-1}^{2}+\delta_{2} h_{s, t-1} \\
& h_{h s, t}=\rho \sqrt{h_{h, t} h_{s, t}}
\end{aligned}
$$

Where $\alpha_{1}^{h}+\beta_{1}^{h}\left(\alpha_{1}^{s}+\beta_{1}^{s}\right)$ represents the speed of adjustment of reverting to the equilibrium after the REIT price (stock price) deviates from the equilibrium in the higher regime of transition function while $\alpha_{1}^{h}\left(\alpha_{1}^{s}\right)$ represents that in the lower regime of the transition function. If $\left|\alpha_{1}^{s}+\beta_{1}^{s}\right|$ is less than $\left|\alpha_{1}^{h}+\beta_{1}^{h}\right|\left(\left|\alpha_{1}^{s}\right|\right.$ is less than $\left|\alpha_{1}^{h}\right|$ ), the stock price has a faster mean reversion to the equilibrium compared to REIT price, which means that the stock price has a greater influence on price discovery than the REIT price (following Sun, Tong and Yan, 2009). Hence, the STVECM is more appropriate to describe the investment behaviours of gradual changes in the different market compositions. The STVECM is governed by the continuous smooth transition function $F\left(Z_{t-d}: \gamma, \tau\right)\left(F\left(\Delta r_{t-d}: \gamma, \tau\right)\right)$. In addition, this study also utilises the STVECM-GARCH model in order to analyse the adjustment speed of reversion to the equilibrium after the respective REIT price in the US and Australia deviates from the long-run equilibrium so as to consider the viewpoint of the investors in both of the REIT markets. According to Terasvirta (1994), two types of the transition function in equation (9) are considered as follows: 


$$
\begin{aligned}
& F\left(Z_{t-d}: \gamma, \tau\right)=\left\{1+\exp \left[-\gamma\left(Z_{t-d}-\tau\right) / \sigma_{Z_{t-d}}\right]\right\}^{-1}, \gamma>0 \\
& F\left(Z_{t-d}: \gamma, \tau\right)=1-\exp \left[-\gamma\left(Z_{t-d}-\tau\right)^{2} / \sigma_{Z_{t-d}}\right], \gamma>0
\end{aligned}
$$

Let us take the STVECM between the stock and REIT prices for example. Equation (9) with transition function (10) is called the logistic STVECM (or LSTVECM), and the LSTVECM represents the different dynamics for the two return regimes with a smooth transition function $F\left(Z_{t-d}: \gamma, \tau\right)=0 \sim 1$ as $Z_{t-d}=-\infty \sim+\infty$. When $\gamma \rightarrow+\infty, F\left(Z_{t-d}: \gamma, \tau\right) \rightarrow 0$ represents the regime of large negative deviations if the stock prices are significantly lower than the REIT prices for $Z_{t-d}<<\tau$ and $F\left(Z_{t-d}: \gamma, \tau\right) \rightarrow 1$ represents the regime of large positive deviations if the stock prices are significantly higher than the REIT prices for $Z_{t-d} \gg \tau$. Equation (9) with transition function (11) is called the exponential STVECM (or ESTVECM). The ESTVECM means that there are different dynamics in the transition regime, but similar dynamics in the extreme regimes since $F\left(Z_{t-d}: \gamma, \tau\right) \rightarrow 1$ as $\left|Z_{t-d}\right| \rightarrow+\infty$. The nonlinear STVECM is only identified under the alternative hypothesis of nonlinearity $H_{0}: \gamma>0$ rather than the null hypothesis of linearity $H_{0}: \gamma=0$. In addition, Luukkonen (1998) proposed that it is feasible to replace $F\left(Z_{t-d}: \gamma, \tau\right)$ with its third-order Taylor approximation of $\gamma=0$. In order to directly examine whether the parameters of the third-order Taylor series in equation (12) are 0 , this study utilises the Wald test as follows:

$$
\begin{aligned}
& \Delta P_{t}^{h}=\pi_{10}+\pi_{11}^{\prime} W_{t}+\kappa_{11}^{\prime} W_{t}\left(Z_{t-d}\right)+\kappa_{12}^{\prime} W_{t}\left(Z_{t-d}\right)^{2}+\kappa_{13}^{\prime} W_{t}\left(Z_{t-d}\right)^{3}+\eta_{1 t} \\
& \Delta P_{t}^{s}=\pi_{20}+\pi_{21}^{\prime} W_{t}+\kappa_{21}^{\prime} W_{t}\left(Z_{t-d}\right)+\kappa_{22}^{\prime} W_{t}\left(Z_{t-d}\right)^{2}+\kappa_{23}^{\prime} W_{t}\left(Z_{t-d}\right)^{3}+\eta_{2 t}
\end{aligned}
$$

Where $W_{t}=\left(Z_{t-1}, \Delta P_{t-1}^{s} \ldots, \Delta P_{t-q}^{s}, \Delta P_{t-1}^{h} \ldots, \Delta P_{t-q}^{h}\right)$. Before estimating the nonlinear STVECM, it is necessary to test for linearity using $F\left(Z_{t-d}: \gamma, \tau\right)=0$ for the delay parameter $d$ with the smallest $p$-value. After the delay parameter $d$ is determined, the linearity test is equivalent to the test of the hypothesis :

$$
H_{0}: \kappa_{11}^{\prime}=\kappa_{12}^{\prime}=\kappa_{13}^{\prime}=\kappa_{21}^{\prime}=\kappa_{22}^{\prime}=\kappa_{23}^{\prime}=0
$$


We use the auxiliary regression (14) as follows.

$$
\begin{aligned}
& \widehat{\varepsilon}_{t}^{h}=\pi_{10}+\pi_{11}^{\prime} W_{t}+\kappa_{11}^{\prime} W_{t}\left(Z_{t-d}\right)+\kappa_{12}^{\prime} W_{t}\left(Z_{t-d}\right)^{2}+\kappa_{13}^{\prime} W_{t}\left(Z_{t-d}\right)^{3}+v_{1 t} \\
& \widehat{\varepsilon}_{t}^{s}=\pi_{20}+\pi_{21}^{\prime} W_{t}+\kappa_{21}^{\prime} W_{t}\left(Z_{t-d}\right)+\kappa_{22}^{\prime} W_{t}\left(Z_{t-d}\right)^{2}+\kappa_{23}^{\prime} W_{t}\left(Z_{t-d}\right)^{3}+v_{2 t}
\end{aligned}
$$

Where $\widehat{\varepsilon}_{t}^{h}\left(\widehat{\varepsilon}_{t}^{s}\right)$ is the residual under the null hypothesis of linearity STVECM. If the STVECM is confirmed, we use the following auxiliary regression:

$$
\begin{aligned}
& \widehat{\varepsilon}_{t}^{h}=\pi_{10}+\pi_{11}^{\prime} W_{t}+\kappa_{11}^{\prime} W_{t}\left(\Delta r_{t-d}\right)+\kappa_{12}^{\prime} W_{t}\left(\Delta r_{t-d}\right)^{2}+\kappa_{13}^{\prime} W_{t}\left(\Delta r_{t-d}\right)^{3}+v_{1 t} \\
& \widehat{\varepsilon}_{t}^{s}=\pi_{20}+\pi_{21}^{\prime} W_{t}+\kappa_{21}^{\prime} W_{t}\left(\Delta r_{t-d}\right)+\kappa_{22}^{\prime} W_{t}\left(\Delta r_{t-d}\right)^{2}+\kappa_{23}^{\prime} W_{t}\left(\Delta r_{t-d}\right)^{3}+v_{2 t}
\end{aligned}
$$

Then, we use the Wald test statistic in order to examine the linear versus nonlinear STVECM.

Moreover, this study utilises a sequence of tests in equation (15) in order to identify whether the LSTVECM or ESTVECM is the suitable model. The null hypothesis for identifying the type of transition is as follows:

$$
\begin{aligned}
& H_{04}: \kappa_{13}^{\prime}=\kappa_{23}^{\prime}=0 \\
& H_{03}: \kappa_{12}^{\prime}=\kappa_{22}^{\prime}=0 \mid \kappa_{13}^{\prime}=\kappa_{23}^{\prime}=0 \\
& H_{02}: \kappa_{11}^{\prime}=\kappa_{21}^{\prime}=0 \mid \kappa_{12}^{\prime}=\kappa_{22}^{\prime}=\kappa_{13}^{\prime}=\kappa_{23}^{\prime}=0
\end{aligned}
$$

If $H_{04}$ is rejected, then the LSTVECM is fitted. If $H_{03}$ is rejected, then the ESTVECM is fitted. If both $H_{04}$ and $H_{03}$ is accepted but $H_{02}$ is rejected, then the LSTVECM should be selected.

\section{The Empirical Results}

\subsection{Results of the co-integration test}

As seen in Table 2, Panel A shows that when structural breaks are considered, there is a non-linear co-integration relationship in at least one model test between US Equity REIT or Mortgage REIT indices and the S\&P 500 indices, respectively. Meanwhile, there is a non-linear co-integration relationship in at least one model test between Australian all REIT indices and its ASX stock indices. There is a nonlinear co-integration relationship in at least one model test between US all REIT indices and Australian all REIT indices. Moreover, the structural break points of the co-integration between the US various-type REIT indices and the S\&P 500 indices fall during the first half of 1999 while the structural break points of the cointegration between Australian all REIT indices and its stock indices fall in 2002. Furthermore, the structural break points of the co-integration between US all REIT indices and Australian all REIT indices fall in 2007. However, there is no non-linear co-integration relationship between Hybrid REIT and the S\&P 500 stock indices. Thus, this study utilises the nonlinear co-integrated equilibrium, which does not 
contain error correction terms that establish the short-run dynamic adjustment model between Hybrid REIT and stock prices.

\subsection{Results of nonlinear test and STVECM}

The results of linearity against the nonlinear test in Tables 3 show significant evidence of non-linearity between the REIT and corresponding stock prices in the US and Australia and between the two REIT prices. In order to determine $d$, we estimate a range of $d$ values $(1 \leq d \leq 6)$, where the $F$ statistics with the minimum $p$ value or the maximum $F$ statistics identify the optimal d value.

Table 3: Nonlinear test of STVECM

\begin{tabular}{|c|c|c|c|c|c|c|}
\hline \multicolumn{7}{|c|}{ Panel A: US REIT and S\&P 500 Stock Indices } \\
\hline $\mathrm{d}$ & 1 & 2 & 3 & 4 & 5 & 6 \\
\hline$H_{0}$ F Stat & 63.0314 & 54.2710 & 58.9111 & 57.3745 & 53.3201 & 43.9632 \\
\hline p-value & 0.0000 & 0.0000 & 0.0000 & 0.0000 & 0.0000 & 0.0001 \\
\hline \multicolumn{7}{|c|}{ HYBRID REITs and S\&P 500 } \\
\hline d & 1 & 2 & 3 & 4 & 5 & 6 \\
\hline$H_{0}$ F Stat & 53.6428 & 31.2420 & 62.1970 & 51.9303 & 28.4243 & 90.2303 \\
\hline p-value & 0.0000 & 0.0018 & 0.0000 & 0.0000 & 0.0048 & 0.0000 \\
\hline \multicolumn{7}{|c|}{ MORTGAGE REITs and S\&P 500 } \\
\hline d & 1 & 2 & 3 & 4 & 5 & 6 \\
\hline$H_{0}$ F Stat & 33.3900 & 38.2819 & 42.5467 & 37.0605 & 32.8731 & 30.3021 \\
\hline p-value & 0.0041 & 0.0008 & 0.0002 & 0.0012 & 0.0049 & 0.0109 \\
\hline \multicolumn{7}{|c|}{ Panel B: AUS REIT and Stock Indices } \\
\hline d & 1 & 2 & 3 & 4 & 5 & 6 \\
\hline$H_{0}$ F Stat & 30.4290 & 28.6041 & 29.6201 & 34.8241 & 35.5418 & 34.5093 \\
\hline p-value & 0.0105 & 0.0181 & 0.0134 & 0.0026 & 0.0021 & 0.0029 \\
\hline \multicolumn{7}{|c|}{ Panel C: US REIT and S\&P 500 Stock Indices } \\
\hline d & 1 & 2 & 3 & 4 & 5 & 6 \\
\hline$H_{0}$ F Stat & 82.9228 & 111.0763 & 89.4587 & 89.4591 & 93.2141 & 55.2317 \\
\hline p-value & 0.0000 & 0.0000 & 0.0000 & 0.0000 & 0.0000 & 0.0000 \\
\hline
\end{tabular}

Note: 1 . The specification and null hypothesis of the nonlinear STVECM are given in equations (14) and (13), respectively. 2. $\mathrm{d}$ is the optimal lag length of the transition variable $Z_{t-d}$.

3. The testing statistics are adopted in the Wald test, and the specification of the testing statistics is listed in equation (15).

The results in Table 4 show that $H_{04}$ is rejected for $d=1$ between Equity REIT and the S\&P 500 indices and between the US and Australian REIT indices as well as for $\mathrm{d}=5$ between the RETI and stock indices in Australia. These results indicate that the LSTVECM is a more appropriate model. However, $H_{03}$ is rejected for $d=1$ between Hybrid REIT and the S\&P 500 indices and for $\mathrm{d}=3$ between Mortgage 
REIT and the S\&P 500 indices, which indicates that the ESTVAR and ESTVECM are more appropriate models.

Table 5 and Table 6 illustrate respectively the short-run dynamic STVECMGARCH (or STVAR-GARCH) estimation results for various types of US REIT and stock index returns, Australian REIT and stock index returns and US and Australian REIT index returns. The estimated parameters, $\psi_{2}, \delta_{2}$ or $\rho$ of STVECM-GARCH (STVAR-GARCH), show that the previous messages from every type of US REIT and stock indices, Australian REIT and stock indices and US and Australian REIT indices all have significant impact on index volatility either individually or collectively. As the Table 5 and the Table 6 show, the results of the STVECM in consistently show positive $\gamma$ smooth parameters and most of them are significantly large, meaning that there is a quick transition from one regime to another. The estimated results of the smooth transition functions in the dynamics between the REIT and corresponding stock indices in the US and Australia as well as between the two REIT indices are listed in equations (17) to (21) below.

Table 4: Model specifications for the LSTVECM vs. ESTVECM

\begin{tabular}{|c|c|c|c|c|c|c|}
\hline \multicolumn{7}{|c|}{ Panel A: US REIT and Stock } \\
\hline \multicolumn{7}{|c|}{ EQUTY REITs and S\&P 500 } \\
\hline $\mathrm{d}$ & Ho4 F Stat & p-value & Ho3 F Stat & p-value & Ho2 F Stat & p-value \\
\hline 1 & 15.2744 & 0.0093 & 12.6248 & 0.0272 & 35.0319 & 0.0000 \\
\hline 2 & 10.8782 & 0.0538 & 14.5147 & 0.0127 & 28.7953 & 0.0000 \\
\hline 3 & 14.5798 & 0.0123 & 20.8810 & 0.0009 & 23.2635 & 0.0003 \\
\hline 4 & 16.1054 & 0.0065 & 13.1231 & 0.0223 & 28.0279 & 0.0000 \\
\hline 5 & 12.0443 & 0.0342 & 7.5312 & 0.1840 & 33.6915 & 0.0000 \\
\hline 6 & 7.6428 & 0.1771 & 7.0586 & 0.2163 & 29.2438 & 0.0000 \\
\hline \multicolumn{7}{|c|}{ HYBRID REITs and S\&P 500 } \\
\hline $\mathrm{d}$ & Ho4 F Stat & p-value & Ho3 F Stat & p-value & Ho2 F Stat & p-value \\
\hline 1 & 2.2000 & 0.6991 & 16.0930 & 0.0029 & 35.3051 & 0.0000 \\
\hline 2 & 1.0201 & 0.9067 & 9.5120 & 0.0500 & 20.7075 & 0.0004 \\
\hline 3 & 23.9905 & 0.0001 & 16.9458 & 0.0020 & 21.1017 & 0.0003 \\
\hline 4 & 30.3724 & 0.0000 & 8.7520 & 0.0676 & 12.7093 & 0.0128 \\
\hline 5 & 9.0083 & 0.0609 & 8.9606 & 0.0621 & 10.4322 & 0.0337 \\
\hline 6 & 29.4803 & 0.0000 & 42.0122 & 0.0000 & 18.3910 & 0.0010 \\
\hline \multicolumn{7}{|c|}{ MORTGAGE REITs and S\&P 500 } \\
\hline $\mathrm{d}$ & Ho4 F Stat & p-value & Ho3 F Stat & p-value & Ho2 F Stat & p-value \\
\hline 1 & 1.8769 & 0.8659 & 17.8870 & 0.0031 & 13.6217 & 0.0182 \\
\hline 2 & 2.2706 & 0.8106 & 30.3425 & 0.0000 & 4.7924 & 0.4417 \\
\hline 3 & 3.4165 & 0.6361 & 34.3194 & 0.0000 & 4.7924 & 0.4417 \\
\hline 4 & 5.2118 & 0.3906 & 25.6019 & 0.0001 & 6.2242 & 0.2850 \\
\hline 5 & 6.4103 & 0.2683 & 18.9551 & 0.0020 & 7.4856 & 0.1870 \\
\hline 6 & 6.6775 & 0.2457 & 18.2100 & 0.0027 & 5.3921 & 0.3699 \\
\hline
\end{tabular}




\begin{tabular}{|c|c|c|c|c|c|c|}
\hline \multicolumn{7}{|c|}{ Panel B: Australian REIT and Stock Indices } \\
\hline $\mathrm{d}$ & Ho4 F Stat & p-value & Ho3 F Stat & p-value & Ho2 F Stat & p-value \\
\hline 1 & 8.8987 & 0.1132 & 12.2584 & 0.0314 & 9.2428 & 0.0998 \\
\hline 2 & 7.2378 & 0.2036 & 11.3245 & 0.0453 & 10.0185 & 0.0747 \\
\hline 3 & 7.3265 & 0.1975 & 12.5237 & 0.0283 & 9.7419 & 0.0829 \\
\hline 4 & 12.7768 & 0.0256 & 12.0983 & 0.0335 & 9.8982 & 0.0782 \\
\hline 5 & 12.4598 & 0.0290 & 11.9163 & 0.0360 & 11.1160 & 0.0491 \\
\hline 6 & 10.1613 & 0.0708 & 13.3223 & 0.0205 & 10.9776 & 0.518 \\
\hline \multicolumn{7}{|c|}{ Panel C: US and Australian REIT Indices } \\
\hline $\mathrm{d}$ & Ho4 F Stat & p-value & Ho3 F Stat & p-value & Ho2 F Stat & p-value \\
\hline 1 & 44.2362 & 0.0000 & 19.9909 & 0.0028 & 18.2500 & 0.0056 \\
\hline 2 & 33.3460 & 0.0000 & 43.8039 & 0.0000 & 33.0793 & 0.0000 \\
\hline 3 & 28.8012 & 0.0001 & 38.1381 & 0.0000 & 21.9706 & 0.0012 \\
\hline 4 & 17.7946 & 0.0068 & 41.2468 & 0.0000 & 29.7229 & 0.0000 \\
\hline 5 & 14.1071 & 0.0285 & 49.0795 & 0.0000 & 29.4949 & 0.0000 \\
\hline 6 & 17.1959 & 0.0086 & 24.9869 & 0.0003 & 12.8696 & 0.0452 \\
\hline
\end{tabular}

Note: 1 . Null hypothesis of the nonlinear model specification for the LSTVECM versus the ESTVECM is given in equation (16).

2. $\mathrm{d}$ is the optimal lag length of the transition variable $Z_{t-d}$.

3. The testing statistics are adopted in the Wald test, and the specification of the testing statistics is given in equation (15).

These results further confirm that the smooth transition functions between Hybrid REIT and stock indices and between Mortgage REIT and stock indices follow the exponential transition type, while those between Equity REIT and stock indices, between REIT and stock indices in the Australia and between the REIT indices in the US and Australia follow the logistic transition type. The transition function between Equity REIT and the S\&P500 indices in equation (17) is estimated as follows:

$$
\begin{aligned}
& F\left(Z_{t-1} \mid \gamma, \tau\right)=\left\{1+\exp \left[-39.655\left(Z_{t-1}-0.151\right)\right]\right\}^{-1} \\
& F\left(Z_{t-1} \mid \gamma, \tau\right)=\left\{1+\exp \left[-3.662\left(Z_{t-1}-0.058\right)\right]\right\}^{-1}
\end{aligned}
$$

The transition function between Mortgage REIT and the S\&P500 indices in equation (18) is estimated as follows:

$$
\begin{aligned}
& F\left(\Delta r_{t-1} \mid \gamma, \tau\right)=\left\{1-\exp \left[-392.258\left(\Delta r_{t-1}-0.070\right)^{2}\right]\right\} \\
& F\left(\Delta r_{t-1} \mid \gamma, \tau\right)=\left\{1-\exp \left[-31.536\left(\Delta r_{t-1}-0.035\right)^{2}\right]\right\}
\end{aligned}
$$

The transition function between Hybrid REIT and the S\&P500 indices in equation (19) is estimated as follows:

$$
\begin{aligned}
& F\left(Z_{t-3} \mid \gamma, \tau\right)=\left\{1-\exp \left[-1.258\left(Z_{t-3}-0.199\right)^{2}\right]\right\} \\
& F\left(Z_{t-3} \mid \gamma, \tau\right)=\left\{1-\exp \left[-6.583\left(Z_{t-3}-0.254\right)^{2}\right]\right\}
\end{aligned}
$$


The transition function between Australian REIT and the ASX stock indices in equation (20) is estimated as follows:

$$
\begin{aligned}
& F\left(Z_{t-5} \mid \gamma, \tau\right)=\left\{1+\exp \left[-844.465\left(Z_{t-5}+0.040\right)\right]\right\}^{-1} \\
& F\left(Z_{t-5} \mid \gamma, \tau\right)=\left\{1+\exp \left[-34.092\left(Z_{t-5}+0.062\right)\right]\right\}^{-1}
\end{aligned}
$$

The transition function between US REIT and Australian REIT indices in equation (21) is estimated as follows:

$$
\begin{aligned}
& F\left(Z_{t-1} \mid \gamma, \tau\right)=\left\{1+\exp \left[-15.435\left(Z_{t-1}+0.159\right)\right]\right\}^{-1} \\
& F\left(Z_{t-1} \mid \gamma, \tau\right)=\left\{1+\exp \left[-8.129\left(Z_{t-1}-0.072\right)\right]\right\}^{-1}
\end{aligned}
$$

The $Z_{t-1}$ coefficients of Mortgage REIT (S\&P 500 stock) indices in the US with large negative and positive deviations are all $-1.470(-0.331)$. The $Z_{t-1}$ coefficients of Equity REIT (S\&P 500 stock) indices in the US with large negative and positive deviations are -1.109 (1.724) and -0.009 (0.036), respectively. The $Z_{t-1}$ coefficients of the REIT (ASX stock) indices in Australia with large negative and positive deviations are $0.126(-0.076)$ and $0.125(-0.456)$, respectively. The $Z_{t-1}$ coefficients of the US REIT (Australian REIT) indices with large negative and positive deviations are $-0.051(20.039)$ and $3.211(-0.744)$, respectively. These results indicate that there are consistently quick and evident mean reversions to the equilibrium for large negative and positive deviations between each-type of REIT and stock indices in the US, between REIT and stock indices in the Australia and between the US and Australian REIT indices. More specifically, regardless of whether large positive deviations (i.e. when the S\&P 500 indices are significantly higher than Mortgage REIT indices), or large negative deviations exist (when the S\&P 500 indices are significantly lower than Mortgage REIT indices), the adjustment speed of the US S\&P 500 indices reversion to equilibrium is greater than that of the Mortgage REIT indices. This may be the reason why investors who simultaneously invest in US Mortgage REITs and S\&P 500 stocks prefer to purchase stocks that offer higher returns, so they purchase stocks more frequently than REITs, pushing the corresponding stock prices back to equilibrium at a faster speed than REIT prices. Moreover, when the S\&P 500 indices are significantly higher than Equity REIT indices (i.e. when there are large positive deviations), the informed traders tend to buy the relatively cheaper Equity REITs. In this case, the incentive to purchase Equity REITs will increase, thus accelerating the adjustment speed of Equity REITs indices reverting to equilibrium. However, when the S\&P 500 indices are significantly lower than Equity REITs indices (i.e. when there are large negative deviations), investors tend to purchase Equity REITs that may offer lower risks and more stable returns, thus pushing the adjustment speed of Equity REITs indices reverting to equilibrium faster than that of their corresponding stock 
indices. In addition, when Australian common stock indices are significantly higher (lower) than its REIT indices (i.e. when there are large positive (negative) deviations), informed traders tend to buy the relatively cheaper REITs (stocks), thus pushing the adjustment speed of REIT (stock) indices reverting to equilibrium faster than that of their corresponding stock (REIT) indices. When U.S. REITs indices are significantly higher (lower) than Australian REIT indices (i.e. when there are large positive (negative) deviations), the informed traders tend to buy relatively cheaper Australian REITs (US REITs), thus pushing the adjustment speed of Australian REIT (U.S. REIT) indices reverting to equilibrium faster than that of U.S. REIT (Australian REIT) indices.

Moreover, the adjustment speeds of U.S. Mortgage REIT and the S\&P 500 indices reverting to equilibrium from large positive or negative deviations are equal, and this may be the reason why the nature of the Mortgage REITs is very similar to that of bonds. Since investments in the Mortgage REITs and S\&P 500 stocks are made to diversify the risk of changes in interest rates, investors of both Mortgage REITs and S\&P 500 stocks have developed very rigid investment habits. Thus, regardless of whether there is a large positive deviation (i.e. stock indices are significantly higher than REIT indices) or a large negative deviation (i.e. stock indices are significantly lower than REIT indices), investors of Mortgage REITs and S\&P 500 stocks basically do not have the incentive to change their investment behaviour, resulting in the equal adjustment speeds of Mortgage REIT and S\&P 500 indices when reverting to equilibrium. However, the speeds of adjustment in reverting to equilibrium of the large positive and negative deviations between US Equity REIT and S\&P 500 indices, between Australian REIT and ASX stock indices, or between US REIT and Australia REIT indices are unequal, and this may be the reason why the nature of Equity REITs is relatively similar to that of stocks, resulting in the possibility that investors' incentives to invest in these REITs and stocks are easy to change.

According to the theoretical models of the interaction between arbitrageurs and noise traders, noise traders further drove prices to show their persistency when there were small deviations. On the contrary, when there are large deviations, the arbitrageurs will be more confident in driving the market in the appropriate direction and price movements will quickly revert to equilibrium. Moreover, this study demonstrates that the ESTVECM is fitted for describing the short-run return dynamics of the deviations from the co-movement equilibrium between Mortgage REIT and S\&P 500 stock prices in the US, while the LSTVECM is more suitable for describing those between Equity REIT and S\&P 500 stock prices in the US, between the REIT and ASX stock prices in the Australia and between the US and Australian REIT prices. That is, the adjustment speeds between Mortgage REIT and S\&P 500 stock prices in the US reverting to equilibrium for the large positive and negative deviations are all equal, while those between Equity REIT and S\&P 500 stock prices in the US, between the REIT and ASX stock prices in the Australia and between the two REIT prices in the US and Australia are unequal.

The REIT prices significantly influence the stock prices, regardless of whether there 
are large positive or negative deviations (or returns) in STVECM between US REITs and stock indices. This may be due to the possibility that REIT markets in the US have the largest market capitalization in the world and more mature investment environments for investors compared to those in other countries. Thus, when the US REIT prices rise, the value of REITs held by American companies will also increase, which pushes up the market capitalization of US enterprises as well as stock prices. Meanwhile, by putting their REITs on mortgages, American investors can borrow more money to invest and stimulate the stock market, thus raising stock prices. Hence, it is confirmed that the 'credit price effect' can commonly exist in the US. In other words, in terms of price discovery, the US REIT markets are more important than the stock markets. Nevertheless, both 'credit price effect' (in which REIT prices clearly influence stock prices) and 'wealth effect' (in which stock prices influence REIT prices) are found in Australia. This may be due to the possibility that Australian REITs and stock markets have equal powers that influence one another. Similarly, US REIT indices significantly influence Australian REIT indices, which show that price discovery is more important in the US REIT market than the Australian REIT market. 
Table 5: Estimated results of models in US REIT and stock indices

\begin{tabular}{|c|c|c|c|c|c|c|c|}
\hline \multicolumn{2}{|c|}{ Items } & \multicolumn{2}{|c|}{$\begin{array}{l}\text { Equity REIT and } \\
\text { Stock Indices }\end{array}$} & \multicolumn{2}{|c|}{$\begin{array}{l}\text { Hybrid REIT and } \\
\text { Stock indices }\end{array}$} & \multicolumn{2}{|c|}{$\begin{array}{l}\text { Mortgage REIT and } \\
\text { Stock Indices }\end{array}$} \\
\hline \multicolumn{2}{|c|}{ Models } & \multicolumn{2}{|c|}{ LSTVECM-GARCH } & \multicolumn{2}{|c|}{ ESTVAR-GARCH } & \multicolumn{2}{|c|}{ ESTVECM -GARCH } \\
\hline \multicolumn{2}{|c|}{ Mean Equations } & $\Delta p_{t}^{h}$ & $\Delta p_{t}^{s}$ & $\Delta p_{t}^{h}$ & $\Delta p_{t}^{s}$ & $\Delta p_{t}^{h}$ & $\Delta p_{t}^{s}$ \\
\hline Constant & $\alpha_{0}$ & $\begin{array}{c}-0.545 \\
(-1.810 * *) \\
\end{array}$ & $\begin{array}{c}0.228 \\
(0.225) \\
\end{array}$ & $\begin{array}{c}0.058 \\
(3.732 * * *) \\
\end{array}$ & $\begin{array}{c}0.037 \\
(2.382 *) \\
\end{array}$ & $\begin{array}{c}0.101 \\
(3.982 * * *) \\
\end{array}$ & $\begin{array}{c}0.053 \\
(2.168 * * *) \\
\end{array}$ \\
\hline $\mathrm{Z}_{\mathrm{t}-1}$ & $\alpha_{1}$ & $\begin{array}{c}-1.109 \\
(-1.927 * *)\end{array}$ & $\begin{array}{c}1.724 \\
(0.675) \\
\end{array}$ & & & $\begin{array}{c}-0.012 \\
(-0.207) \\
\end{array}$ & $\begin{array}{c}0.079 \\
(1.000) \\
\end{array}$ \\
\hline$\Delta p_{t-1}^{h}$ & $\alpha_{2}$ & $\begin{array}{c}0.239 \\
(4.357 * * *) \\
\end{array}$ & $\begin{array}{c}-0.357 \\
(-0.318) \\
\end{array}$ & $\begin{array}{c}0.035 \\
\left(1.861^{*}\right) \\
\end{array}$ & $\begin{array}{c}0.006 \\
(0.660) \\
\end{array}$ & $\begin{array}{c}0.140 \\
(-0.207) \\
\end{array}$ & $\begin{array}{c}0.005 \\
(0.402) \\
\end{array}$ \\
\hline$\Delta p_{t-1}^{s}$ & $\alpha_{3}$ & $0.019(0.672)$ & $\begin{array}{c}2.447 \\
(0.474)\end{array}$ & $\begin{array}{c}-0.017 \\
(-1.334)\end{array}$ & $\begin{array}{c}-0.045 \\
(-4.377 * * *)\end{array}$ & $\begin{array}{c}-0.017 \\
(-0.737)\end{array}$ & $\begin{array}{c}-0.051 \\
(-2.126 * *)\end{array}$ \\
\hline Constant & $\beta_{0}$ & $\begin{array}{c}0.640 \\
(2.111 * * *) \\
\end{array}$ & $\begin{array}{c}-0.192 \\
(-0.186)\end{array}$ & $\begin{array}{c}-4.971 \\
(-0.003)\end{array}$ & $\begin{array}{c}2.684 \\
(0.001) \\
\end{array}$ & $\begin{array}{c}-1.202 \\
(-2.533 * *)\end{array}$ & $\begin{array}{c}-0.134 \\
(-0.960)\end{array}$ \\
\hline $\mathrm{Z}_{\mathrm{t}-1}$ & $\beta_{1}$ & $\begin{array}{c}1.100 \\
\left(1.768^{*}\right)\end{array}$ & $\begin{array}{l}-1.688 \\
(-0.643)\end{array}$ & & & $\begin{array}{c}-1.458 \\
(-2.456 * *)\end{array}$ & $\begin{array}{c}-0.410 \\
(-2.751 * * *)\end{array}$ \\
\hline$\Delta p_{t-1}^{h}$ & $\beta_{2}$ & $\begin{array}{c}-0.237 \\
(-3.944 * * *) \\
\end{array}$ & $\begin{array}{c}0.368 \\
(0.326) \\
\end{array}$ & $\begin{array}{c}-0.323 \\
(-0.005) \\
\end{array}$ & $\begin{array}{c}0.537 \\
(0.006) \\
\end{array}$ & $\begin{array}{c}-1.637 \\
(-3.037 * * *) \\
\end{array}$ & $\begin{array}{c}-0.066 \\
(-1.505) \\
\end{array}$ \\
\hline$\Delta p_{t-1}^{s}$ & $\beta_{3}$ & $\begin{array}{c}-0.057 \\
(-1.605) \\
\end{array}$ & $\begin{array}{l}-2.544 \\
(-0.492) \\
\end{array}$ & $\begin{array}{c}-1.937 \\
(-0.015) \\
\end{array}$ & $\begin{array}{c}0.688 \\
(0.002) \\
\end{array}$ & $\begin{array}{c}0.010 \\
(0.033) \\
\end{array}$ & $\begin{array}{c}0.011 \\
(0.180) \\
\end{array}$ \\
\hline $\begin{array}{l}\text { Transition } \\
\text { Speed }\end{array}$ & $\gamma$ & $\begin{array}{l}39.655 \\
(1.344) \\
\end{array}$ & $\begin{array}{c}3.662 \\
(1.109) \\
\end{array}$ & $\begin{array}{c}392.258 \\
(0.122)\end{array}$ & $\begin{array}{l}31.536 \\
(0.105) \\
\end{array}$ & $\begin{array}{c}1.258 \\
\left(3.858^{* * *}\right)\end{array}$ & $\begin{array}{c}6.583 \\
\left(1.655^{*}\right) \\
\end{array}$ \\
\hline $\begin{array}{l}\text { Threshold } \\
\text { Parameter }\end{array}$ & $\tau$ & $\begin{array}{c}0.151 \\
(1.559) \\
\end{array}$ & $\begin{array}{c}0.058 \\
(2.383 * *) \\
\end{array}$ & $\begin{array}{c}0.070 \\
(0.030) \\
\end{array}$ & $\begin{array}{c}0.035 \\
(0.053) \\
\end{array}$ & $\begin{array}{c}0.199 \\
(3.038 * * *) \\
\end{array}$ & $\begin{array}{c}0.254 \\
\left(1.715^{*}\right) \\
\end{array}$ \\
\hline \multicolumn{2}{|c|}{$\begin{array}{c}\text { Variance and } \\
\text { Covariance } \\
\text { Equations }\end{array}$} & $h_{h, t}$ & $h_{s, t}$ & $h_{h, t}$ & $h_{s, t}$ & $h_{h, t}$ & $h_{s, t}$ \\
\hline Constant & $\phi_{0}, \delta_{0}$ & $\begin{array}{c}0.028 \\
(6.961 * * *)\end{array}$ & $\begin{array}{c}0.0106 \\
(4.481 * * *)\end{array}$ & $\begin{array}{c}0.028 \\
(64.243 * * *) \\
\end{array}$ & $\begin{array}{c}0.010 \\
(73.310 * * *) \\
\end{array}$ & $\begin{array}{c}0.066 \\
(13.627 * * *) \\
\end{array}$ & $\begin{array}{c}0.009 \\
(13.826 * * *) \\
\end{array}$ \\
\hline$\varepsilon_{h, t-1}^{2}, \varepsilon_{s, t-1}^{2}$ & $\phi_{1}, \delta_{1}$ & $\begin{array}{c}0.126 \\
(12.138 * * *) \\
\end{array}$ & $\begin{array}{c}0.065 \\
(10.335 * * *) \\
\end{array}$ & $\begin{array}{c}0.121 \\
(13.632 * * *) \\
\end{array}$ & $\begin{array}{c}0.064 \\
(88.386 * * *) \\
\end{array}$ & $\begin{array}{c}0.170 \\
(19.448 * * *)\end{array}$ & $\begin{array}{c}0.065 \\
(39.312 * * *)\end{array}$ \\
\hline$h_{h, t-1}, h_{s, t-1}$ & $\phi_{2}, \delta_{2}$ & $\begin{array}{c}0.856 \\
(70.041 * * *) \\
\end{array}$ & $\begin{array}{c}0.928 \\
(79.782 * * *) \\
\end{array}$ & $\begin{array}{c}0.860 \\
\left(114.558^{* * *}\right) \\
\end{array}$ & $\begin{array}{c}0.929 \\
\left(504.577^{* * *}\right) \\
\end{array}$ & $\begin{array}{c}0.818 \\
(101.352 * * *) \\
\end{array}$ & $\begin{array}{c}0.930 \\
\left(602.021^{* * *}\right) \\
\end{array}$ \\
\hline$h_{h . s, t}$ & $\rho$ & \multicolumn{2}{|c|}{$0.620(61.112 * * *)$} & \multicolumn{2}{|c|}{$0.498\left(36.971^{* * *}\right)$} & \multicolumn{2}{|c|}{$0.485\left(47.410^{* * *}\right)$} \\
\hline
\end{tabular}

Notes: 1. The specifications of the STVECM and VECM are given in equations (9)

2. The numbers in ( ) indicate the t-statistics.

3. **, $* *$ and $*$ denote significance at the $1 \%, 5 \%$ and $10 \%$ levels, respectively. 
Table 6: Estimated results of models of Australian REIT and stock indices, US REIT and Australian REIT indices

\begin{tabular}{|c|c|c|c|c|c|}
\hline \multicolumn{2}{|c|}{ Items } & \multicolumn{2}{|c|}{$\begin{array}{c}\text { Australian REIT and } \\
\text { Stock Indices } \\
\text { LSTVECM-GARCH }\end{array}$} & \multicolumn{2}{|c|}{$\begin{array}{c}\text { US REIT and Australian } \\
\text { REIT Indices } \\
\text { LSTVECM-GARCH }\end{array}$} \\
\hline \multicolumn{2}{|c|}{$\frac{\text { Models }}{\text { Mean Equations }}$} & $\Delta p_{t}^{h}$ & 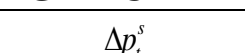 & \multirow{2}{*}{$\begin{array}{c}\Delta p_{t}^{h 1} \\
0.092 \\
\left(4.210^{* * *}\right)\end{array}$} & \multirow{2}{*}{$\begin{array}{c}\Delta p_{t}^{h 2} \\
11.733 \\
(0.847)\end{array}$} \\
\hline Constant & $\alpha_{0}$ & $\begin{array}{c}0.122 \\
(10.620 * * *)\end{array}$ & $\begin{array}{c}0.024 \\
\left(2.211^{* *}\right)\end{array}$ & & \\
\hline $\mathrm{Z}_{\mathrm{t}-1}$ & $\alpha_{1}$ & $\begin{array}{c}0.126 \\
(2.623 * * *)\end{array}$ & $\begin{array}{c}-0.076 \\
(-1.799 *)\end{array}$ & $\begin{array}{c}-0.051 \\
(-0.293)\end{array}$ & $\begin{array}{l}20.039 \\
(0.867)\end{array}$ \\
\hline$\Delta p_{t-1}^{h}$ & $\alpha_{2}$ & $\begin{array}{c}0.004 \\
(0.261)\end{array}$ & $\begin{array}{l}-0.0085 \\
(-0.675)\end{array}$ & $\begin{array}{l}0.020 \\
(0.864)\end{array}$ & $\begin{array}{c}-0.467 \\
(-0.732)\end{array}$ \\
\hline$\Delta p_{t-1}^{s}$ & $\alpha_{3}$ & $\begin{array}{c}0.017 \\
(0.988)\end{array}$ & $\begin{array}{c}-0.010 \\
(-0.572)\end{array}$ & $\begin{array}{c}-0.030 \\
(-0.989)\end{array}$ & $\begin{array}{c}0.858 \\
(0.894)\end{array}$ \\
\hline Constant & $\beta_{0}$ & $\begin{array}{c}-0.100 \\
(-8.124 * * *)\end{array}$ & $\begin{array}{c}0.254 \\
\left(10.066^{* * *}\right)\end{array}$ & $\begin{array}{c}-0.516 \\
(-1.928 *)\end{array}$ & $\begin{array}{l}-11.779 \\
(-0.848)\end{array}$ \\
\hline $\mathrm{Z}_{\mathrm{t}-1}$ & $\beta_{1}$ & $\begin{array}{c}-0.001 \\
(-0.014)\end{array}$ & $\begin{array}{c}-0.380 \\
\left(-4.405^{* * *}\right)\end{array}$ & $\begin{array}{c}3.262 \\
(1.681)\end{array}$ & $\begin{array}{l}-19.295 \\
(-0.840)\end{array}$ \\
\hline$\Delta p_{t-1}^{h}$ & $\beta_{2}$ & $\begin{array}{c}0.032 \\
(1.553)\end{array}$ & $\begin{array}{c}0.063 \\
\left(1.981^{* * *}\right)\end{array}$ & $\begin{array}{c}-0.434 \\
(-5.421 * * *)\end{array}$ & $\begin{array}{c}0.674 \\
(1.055)\end{array}$ \\
\hline$\Delta p_{t-1}^{s}$ & $\beta_{3}$ & $\begin{array}{c}-0.124 \\
\left(-6.665^{* * *}\right)\end{array}$ & $\begin{array}{c}-0.128 \\
\left(-3.1636^{* * *}\right)\end{array}$ & $\begin{array}{c}0.237 \\
(1.508)\end{array}$ & $\begin{array}{c}-0.945 \\
(-0.980)\end{array}$ \\
\hline $\begin{array}{l}\text { Transition } \\
\text { Speed }\end{array}$ & $\gamma$ & $\begin{array}{c}844.465 \\
(1.607)\end{array}$ & $\begin{array}{c}34.092 \\
(15.720 * * *)\end{array}$ & $\begin{array}{l}15.435 \\
(0.197)\end{array}$ & $\begin{array}{c}8.129 \\
(3.153 * *)\end{array}$ \\
\hline $\begin{array}{l}\text { Threshold } \\
\text { Parameter }\end{array}$ & $\tau$ & $\begin{array}{l}-0.040 \\
(-1.199) \\
\end{array}$ & $\begin{array}{c}-0.062 \\
(-13.652 * * *) \\
\end{array}$ & $\begin{array}{c}-0.159 \\
(-4.401 * * *) \\
\end{array}$ & $\begin{array}{c}0.072 \\
(5.713 * * *) \\
\end{array}$ \\
\hline \multicolumn{2}{|c|}{$\begin{array}{l}\text { Variance and } \\
\text { Covariance } \\
\text { Equations }\end{array}$} & $h_{h, t}$ & $h_{s, t}$ & $h_{h, t}$ & $h_{s, t}$ \\
\hline Constant & $\phi_{0}, \delta_{0}$ & $\begin{array}{c}0.013 \\
(13.179 * * *)\end{array}$ & $\begin{array}{c}0.012 \\
(15.204 * * *)\end{array}$ & $\begin{array}{c}0.027 \\
(4.728 * * *)\end{array}$ & $\begin{array}{c}0.014 \\
(4.680 * * *)\end{array}$ \\
\hline$\varepsilon_{h, t-1}^{2}, \varepsilon_{s, t-1}^{2}$ & $\phi_{1}, \delta_{1}$ & $\begin{array}{c}0.087 \\
(51.512 * * *)\end{array}$ & $\begin{array}{c}0.087 \\
\left(41.669^{* * *}\right)\end{array}$ & $\begin{array}{c}0.144 \\
\left(10.119^{* * *}\right)\end{array}$ & $\begin{array}{c}0.098 \\
(8.798 * * *)\end{array}$ \\
\hline$h_{h, t-1}, h_{s, t-1}$ & $\phi_{2}, \delta_{2}$ & $\begin{array}{c}0.901 \\
\left(566.770^{* * *}\right)\end{array}$ & $\begin{array}{c}0.897 \\
(501.108 * * *)\end{array}$ & $\begin{array}{c}0.858 \\
(70.041 * * *)\end{array}$ & $\begin{array}{c}0.890 \\
(79.782 * * *)\end{array}$ \\
\hline$h_{h, s, t}, h_{h l . h 2, t}$, & $\rho$ & 0.534 & $158 * * *)$ & 0.122 & $369 * * *)$ \\
\hline
\end{tabular}

Notes: 1. The specifications of the STVECM and VECM are given in equations (9)

2. The numbers in ( ) indicate the t-statistics.

$3 . * *, * *$ and $*$ denote significance at the $1 \%, 5 \%$ and $10 \%$ levels, respectively. 


\section{Conclusion}

This study utilised the co-integration test with structural breaks proposed by Gregory and Hansen (1996) in order to test whether non-linear co-integration relationships exist between US REITs and stock indices, between Australian REIT and stock indices and between US REITs and Australian REIT indices. Moreover, we used a GARCH-included STVECM to separately explore the adjustment efficiencies of the US and Australian REIT and corresponding stock prices as well as the two countries' REIT prices when there are deviations in long-run equilibrium between the US and Australian REIT indices (Chen and Patel, 1998). Furthermore, this study used the non-linear Granger causality test mentioned by Hiemstra and Jones (1994) to analyse whether 'wealth effect' (in which stock prices influence REIT prices) or 'credit price effect' (in which REIT prices influence stock prices) exists in the US and Australian markets. We also attempted to discover where a price discovery function existed in the US or Australian REIT markets. Our results showed that there are non-linear structural break co-integration relationships between the US Equity and Mortgage REIT indices and corresponding stock indices, between Australian REIT and stock indices and between the US and Australian REIT indices, respectively. Moreover, the results of a nonlinear Granger causality test found that there is a credit price effect in which the various types of US REIT indices influence stock indices regardless of whether large positive or negative deviations (or returns) in STVECM (or STVAR) occur (see the Table 7). Nevertheless, the so-called credit price effect and the wealth effect simultaneously exist in Australian REIT and stock markets. In addition, the price discovery function is more important in the US REIT market than the Australian REIT market.

Table 7: Results of the nonlinear Granger causality test

\begin{tabular}{|c|c|c|}
\hline \multicolumn{3}{|c|}{ Panel A: US Equity REIT and Stock Indices } \\
\hline \multicolumn{3}{|c|}{ Equity REIT and Stock Indices } \\
\hline Large Positive Deviation & $(-0.900)$ & $(3.617 * * *)$ \\
\hline Large Negative Deviation & $(-1.149)$ & $\left(2.191^{* *}\right)$ \\
\hline \multicolumn{3}{|c|}{ Hybrid REIT and Stock Indices } \\
\hline Large Positive Deviation & $(0.759)$ & $\left(2.459^{* * *}\right)$ \\
\hline Large Negative Deviation & $(-0.597)$ & $\left(2.300^{* *}\right)$ \\
\hline \multicolumn{3}{|c|}{ Mortgage REIT and Stock Indices } \\
\hline Large Positive Deviation & $(-0.160)$ \\
\hline Large Negative Deviation & $(0.932)$ & $(3.374 * * *)$ \\
\hline \multicolumn{3}{|c|}{ Panel B: Australian REIT and Stock Indices } \\
\hline Large Positive Deviation & $\left(1.312^{*}\right)$ \\
\hline Large Negative Deviation & $(4.14 * * *)$ & $\left(1.643^{*}\right)$ \\
\hline \multicolumn{3}{|c|}{ Panel C: US and Australian REIT Indices } \\
\hline Large Positive Deviation & $(0.079)$ & $\left(3.55^{* * *}\right)$ \\
\hline Large Negative Deviation & $(-0.21)$ & $\left(2.516^{* *}\right)$ \\
\hline
\end{tabular}

Notes: 1. The numbers in ( ) indicate the t-statistics.

2. ***, $* *$ and $*$ denote significance at the $1 \%, 5 \%$ and $10 \%$ levels, respectively. 
In sum, the return dynamics governing the small deviations were obviously different from those governing the large deviations. Furthermore, our results showed that in order to diversify the risk of changes in interest rates, investors included rigid habits in investing toward bond-type US Mortgage REITs and S\&P 500 stocks. As a result, their adjustment speeds when reverting to equilibrium had a tendency to be equal when there were large positive or negative deviations. However, the REITs investments in US Equity REIT and stock indices, Australian REIT and stock indices and the US and Australian REIT indices were mainly stock-type Equity REITs of which the investors were more likely to change their investing incentives. Therefore, the short-run adjustment speeds when reverting to equilibrium for the large negative and positive deviations were unequal. Specifically speaking, when large positive and negative deviations from the equilibrium between US Mortgage REIT and S\&P 500 stock indices exist, the adjustment speed of stock indices reverting to equilibrium was greater than that of REIT indices. Meanwhile, the adjustment speed of US Equity REIT and S\&P 500 indices when reverting to equilibrium for large negative and positive deviations was different, but the adjustment speed of Equity REIT indices when reverting to equilibrium was greater than that of stock indices. However, when there was a large positive deviation in the Australian REIT and stock indices, the adjustment speed of the REIT indices when reverting to equilibrium was faster than that of corresponding stock indices. In this case, when there was a large negative deviation, this conclusion is reversed. Contributions toward this paper include the following. We use a model that allowed the time-series variables to exist in the structural breaks and the self-decided structure break point to examine whether the non-linear co-integration with structural breaks exists between the US and Australia REIT indices and corresponding stock indices as well as between the respective REIT indices. Moreover, we confirm that STVECM with GARCH can be applied to analyse the efficiency of short-run dynamic adjustment in mean reversion when there are deviations from the equilibrium between the US, Australian REIT and corresponding stock indices and between the US and Australian REIT indices, respectively. On the one hand, the STVECM used by this study confirms that the US S\&P 500 index plays a driver role when reverting to equilibrium between Mortgage REIT and corresponding stock indices while US Equity REIT index plays a driver role when reverting to equilibrium between Equity REIT and corresponding stock indices. Meanwhile, the remaining indices in the STVECM include different adjustment speeds when reverting to equilibrium when large positive and negative deviations from the equilibrium occur. On the other hand, we also confirm that credit price effects exist in each type of US REIT and the stock market regardless of whether large positive or negative deviations (or returns) occur in STVECM. However, there is a feedback effect between Australian REIT and stock markets as well as a price discovery between the US REIT market and the Australian REIT market. Based on the above results and analysis, this paper can serve as an informative reference for investors planning to invest in either the US or Australia. 


\section{References}

[1] Chau, K.W., Ma, S.M., and Ho, D.C.W. (2000). The pricing of luckiness in the apartment market. Journal of Real Estate Literature, 9(1), 31-40.

[2] Green, R.K. (2002). Stock prices and house prices in California: new evidence of a wealth effect? Regional Science and Urban Economics, 32, 775-783.

[3] Gregory, A.W. and Hansen, B.E. (1996). Residual-based tests for cointegration in models with regime shifts. Journal of Econometrics, 70(1), 99-126.

[4] Hiemstra, C. and Jones, J.D. (1994). Testing for linear and nonlinear granger causality in the stock price-volume relation. The Journal of Finance, 49, 16391664.

[5] Hui, E.C.M. and Yue, S. (2006). Housing price bubbles in Hong Kong, Beijing and Shanghai: a comparative study. Journal of Real Estate Finance and Economics, 33(4), 299.

[6] Kapetanios, G., Shin, Y., and Snell, A. (2003). Testing for a unit root in the nonlinear STAR framework. Journal of Econometrics, 112, 359-379.

[7] Larson, S. (2005). Real estate investment trusts and stock price reversals. Journal of Real Estate Finance and Economics, 30, 81-88.

[8] Liow, K.H. and Yang, H. (2005). Long-term co-memories and short run adjustment: securitized real estate and stock markets. Journal of Real Estate Finance and Economics, 31(3), 283-300.

[9] Luukkonen, T. (1998). The difficulties in assessing the impact of EU framework programmes. Research Policy, 27(6), 599-610.

[10] Okunev, J., Wilson, P., and Zurbruegg, R. (2002). Relationships between Australian real estate and stock market prices: a case of market inefficiency. Journal of Forecasting, 21, 181-192.

[11] Oppenheimer, P. and Grissom, T.V. (1998). Frequency space correlation between REITs and capital market indices. Journal of Real Estate Research, 16, 291-310.

[12] Peng, C.W. and Chang J.E. (2000). The influence of macroeconomic variables on real estate cycles in Taiwan. Proceedings of the National Science Council. Part C, Humanities and Social Sciences, 10(3), 330-343.

[13] Tuluca, S., Myer, F. and Webb, J.R., (2000). Dynamics of private and public real estate markets. Journal of Real Estate Finance and Economics, 21(3), 279296.

[14] Su, C.W. (2011). Non-linear causality between the stock and real estate markets of Western European countries: Evidence from rank tests. Economic Modelling, 28, 845-851.

[15] Su, C.W., Chang, H.L., and Zhu, M.N. (2011). A non-linear model of causality between the stock and real estate markets of European countries. Romanian Journal of Economic Forecasting, 1, 41-52.

[16] Sun, Q., Tong, W.H.S., and Yang, Y. (2009). Market liberalization within a country. Journal of Empirical Finance, 16, 18-41. 
[17] Terasvirta, T. (1994). Specification, estimation, and evaluation of smooth transition autoregressive models. Journal of American Statistic Association, 89, 281-312.

[18] Tuluca, S.A., Myer, F.N., and Webb, J.R. (2000). Dynamics of private and public real estate markets. The Journal of Real Estate Finance and Economics, 21(3), 279-296.

[19] Wilson, P. and Okunev, J. (1997). Using nonlinear tests to examine integration between real estate and stock markets. Real Estate Economics, 25(3), 487-503.

[20] Wilson, P. and Okunev, J. (1999). Long-term dependencies and long run nonperiodic co-cycles: real estate and stock markets. Journal of Real Estate Research, 18(2), 257-278. 